\title{
ELECTROCHEMICAL BIOSENSORS AS A TOOL FOR THE INVESTIGATION OF DNA STRUCTURE, DAMAGE AND INTERACTION WITH OTHER MOLECULES ${ }^{\dagger}$
}

UDC $681.586 .74: 577.212$

\author{
Mara M. Aleksić ${ }^{1 *}$, Vera Kapetanović ${ }^{2}$ \\ ${ }^{1}$ University of Belgrade, Faculty of Pharmacy, Department of Physical Chemistry and \\ Instrumental Methods, Vojvode Stepe 450, 11221 Belgrade, Serbia \\ ${ }^{2}$ University of Belgrade, Faculty of Pharmacy, Department of Analytical Chemistry, \\ Vojvode Stepe 450, 11221 Belgrade, Serbia
}

\begin{abstract}
In recent years, a great progress was achieved in the development of electrochemical sensors for DNA sequences, hybridization and damage. Nowadays, electrochemical methods are able to detect DNA at nanomolar concentration. In addition, these methods are suitable for studding both covalent and non-covalent binding interactions between DNA and different small molecules, e.g. drugs or potentially mutagenic agents. This suggests that electrochemical biosensors might become important tools in medical research. The aim of this review is to draw attention to the applicability of different electrochemical techniques for studying interactions between DNA with other molecules, and in the design of new sensitive and selective biosensors.
\end{abstract}

Key words: Electrochemical biosensor, DNA, binding interaction, damage

\section{INTRODUCTION}

Deoxyribonucleic acid, DNA, [1-3], is a natural product of an enormous importance for the functioning of genetic processes such as growth, differentiation and aging of the cell. Binding of small organic and inorganic molecules to DNA can influence numerous biological processes in which DNA participate, like transcription and replication $[2,3]$. These processes begin when DNA receives the signal from regulatory protein which binds to its particular part. If, instead of the regulatory protein, some other small molecule binds to DNA, its function is artificially changed-inhibited or activated. Such interference can retard or even prevent the cell growth, or, on the other hand, it can lead to excessive production of some protein and uncontrolled cell growth. In the case when the activation or

Received July $15^{\text {th }}, 2013$; revised October $19^{\text {th }}, 2013$; accepted November $04^{\text {th }}, 2013$.

$\dagger$ Acknowledgement: This work was supported by the Ministry of Education, Science and Technological Development of the Republic of Serbia, Project No. 172033.

* Contact of the corresponding author: mara@pharmacy.bg.ac.rs. 
inhibition of the DNA functions act in the way to cure or control the disease, small molecule is denoted as a drug, otherwise it is cytotoxic agents.

When the complex between small molecules and DNA is formed, both molecules, as well as DNA, experienced some modifications. Detection and explanation of these changes makes a great challenge for new instrumental methods. The development of the electrochemical DNA biosensors has opened a wide perspective using particularly sensitive and selective electrochemical methods for the detection of specific DNA interactions. The obtained results are used to understand the correlation between DNA structure, sequence and activity, to confirm the DNA damage, to determine drug binding sites and sequence preference, as well as conformational changes due to DNA-drug interaction.

The aim of this review is to give the overview of the present state of DNA electrochemical analysis. The presented results summarize literature data obtained by the application of electrochemical biosensors, their operation and detection principles, with emphasis on the use of the covalently or non-covalently bound redox indicators for increasing the sensitivity of the measurements. The brief summary of the DNA structural characteristic and types of interactions will be discussed before presenting the basic biosensor working principles.

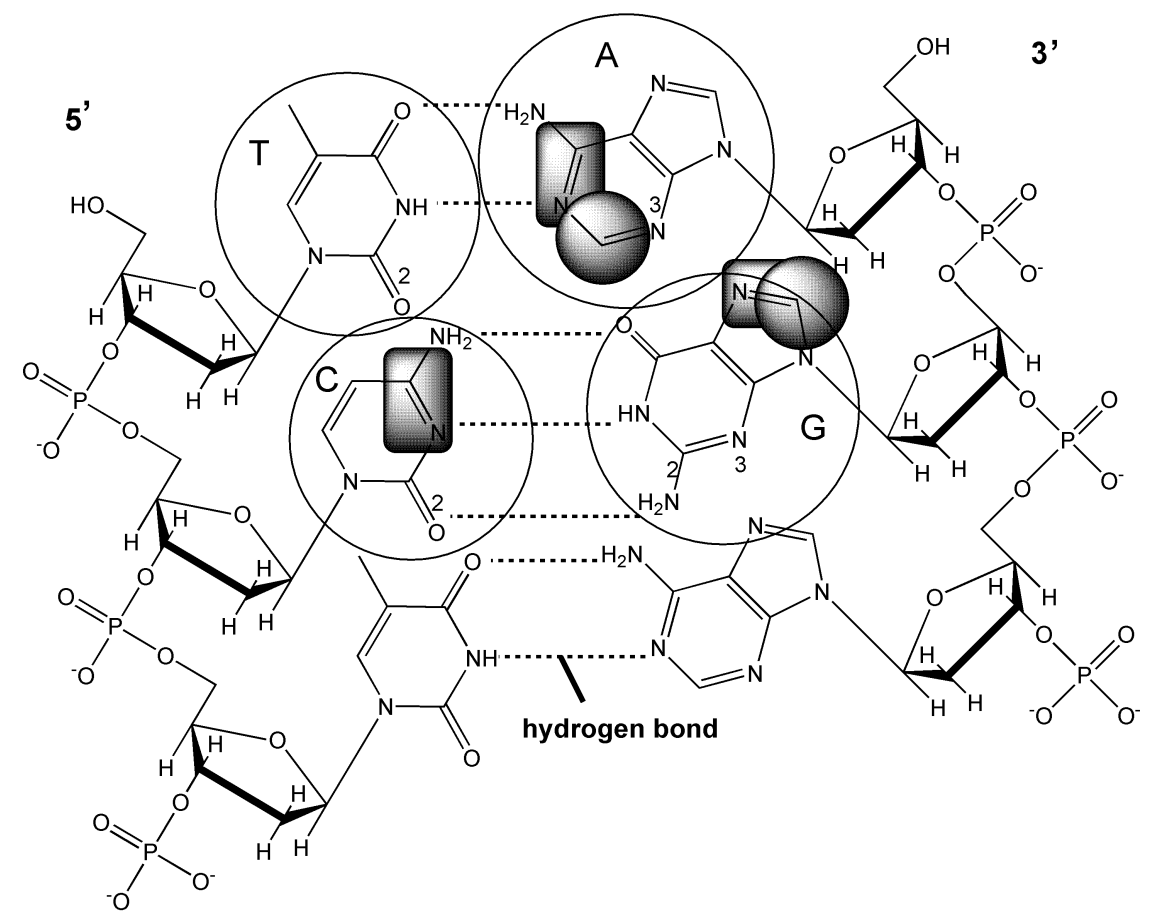

Fig. 1 Structure of double stranded DNA. Squares denote electroactive groups that can be reduced at mercury electrodes, and circles show sites oxidized at carbon electrodes. 


\section{STRUCTURAL CHARACTERISTICS AND ELECTROCHEMICAL ACTIVITY OF DNA MOLECULE}

Deoxyribonucleic acid, DNA, [1-3] consists of two long polynucleotide chains composed of four types of nucleotide subunits. The nucleotides themselves are composed of five-carbon sugars (deoxyribose) to which one or more phosphate groups and a nitrogencontaining base are attached. Base may be either adenine $(A)$, cytosine $(C)$, guanine $(\mathrm{G})$, or thymine $(\mathrm{T})$. The nucleotides are covalently linked together in a chain through the sugars and phosphates, which thus form a "backbone" of alternating sugar and phosphate. The DNA secondary structure is represented by the double helix which consists of two antiparallel polynucleotide chains that are held together by hydrogen bonding between the bases of the different strands, where all the bases are situated inside of the sugar-phosphate backbones of the double helix (Figure 1).

Electrochemical activity of DNA is a consequence of the redox properties of nucleobases. Guanine and adenine residues are oxidized at carbon electrodes, while cytosine and adenine residues are reduced at mercury electrodes, in aqueous solutions at neutral $\mathrm{pH}$. Thymine $(\mathrm{T})$ is reduced only in non aqueous media at highly negative potentials [4-9]. Electroactive groups that undergoes oxidation or reduction processes are presented at Figure 1.

\subsection{DNA interactions in aqueous environment}

In aqueous solution DNA is polyanion attracting positively charged counter ions $\left(\mathrm{Na}^{+}\right.$, $\mathrm{Ca}^{2+}$ or $\mathrm{Mg}^{2+}$ ). Drug molecules are also often charged and thus associated with counter ions. The associated counter ions lie near the charged groups and are also partially solvated. When the binding occurs, it results in a displacement of solvent from the binding site on both the DNA and drug. Also, since there would be partial compensation of charges as the DNA and the drug are oppositely charged, some counter ions would be released into the bulk solvent fully solvated. Besides the counter ion effect, there are other interactions that must be considered, e.g. hydration/dehydration process which occurs through drug-solvent (hydration shell) and DNA-solvent interaction. Hydration plays very important role in the stability of DNA molecule, as well as DNA complex, since this process is believed to be governing by the base sequence, also.

Parts of a DNA molecule that can interact with small molecules are: negatively charged phosphate backbone (electrostatic interactions), the hydrogen accepting and donating sites in the minor and major grooves (H-bonds), the phosphate oxygen atoms and aromatic hydrophobic components (van der Waals interactions).

\section{ELECTROCHEMICAL BIOSENSORS}

According to International Union of Pure and Applied Chemistry (IUPAC) an electrochemical biosensor is a self-contained integrated device, which is capable of providing specific quantitative or semi-quantitative analytical information using a biological recognition element (biochemical receptor) which is retained in direct spatial contact with an electrochemical transduction element [10]. The biological recognition system translates information from the biochemical domain, into a chemical or physical output signal with a defined sensitivity. The main purpose of the recognition system is to provide the sensor with a high degree of selectivity for the analyte to be measured. The transducer part of the sensor 
serves to transfer the signal from the output domain of the recognition system, mostly to the electrical domain $[11,12]$. Electrochemical biosensors intended to detect DNA presence or hybridization, DNA damage, or the binding of molecules to DNA.

During the last decade of the $20^{\text {th }}$ century, DNA oligomers have been utilized as selective bio-recognition elements in new group of affinity biosensors. These so called DNA-based biosensors possess specificity of the response taking advantage of the bioaffinity properties of DNA. However, in contrast to conventional enzyme- and imunosensors, the DNA biosensors are mostly used for the investigation of interactions of DNA itself rather than for typical determination of the concentration of an analyte [13-15]. An electrochemical DNA biosensor can be characterized as a device that integrates DNA as the biological recognition element and an electrode as the electrochemical transducer. It is often presented as an electrode chemically modified by nucleic acid. Advantages and successful use of the electrochemical DNA biosensors were reported and reviewed in numerous papers [16-22].

\subsection{Operation principles}

The signal obtained at the modified electrode surface is transduced into the electrical signal. The measurement can be carried out both amperometrically and potentiometrically. In amperometric measurements, an external potential is applied to oxidize or to reduce an electrochemically active compound at its intrinsic redox potential, and the current produced during the process is measured. In potentiometric measurements, equilibrium is reached at the electrode surface without the need of the external potential, and as a consequence, the equilibrium potential between the electrode and the measured solution is generated and recorded $[10,11]$. The possibility of setting the working potential to the specific redox value of the analyte of interest provides the greater selectivity for the amperometric detection. The procedure usually includes the following three steps: 1) DNA immobilization on the electrode surface, 2) dipping the electrode into analyte solution, and 3) measuring of the current response. The first two steps are performed under the continuous stirring of the solution in order to ensure the adequate mass transport. If the measurement of the current response is performed from the same solution, it is always done after a quiescent period, or alternatively the measurements can be done applying the transfer technique: transferring the electrode with an adsorbed layer to a blank background electrolyte. The measured current intensity depends on the concentration of the analyte following the Cottrel's equation:

$$
I=n F A \frac{D^{1 / 2}}{\pi^{1 / 2} t^{1 / 2}} C
$$

where $A$ represents the area of the electrode, $D$ is diffusion coefficient, $C$ is concentration of the analyte, $t$ is time during which the measurement is performed, and $n$ is the number of exchanged electrons in the electrode process. The electrode used as transducer element can be made up from different materials such as platinum, gold, mercury, pyrolytic graphite, glassy carbon or carbon paste. The use of solid conductors dispersed into polymeric nonconducting matrices - composites, and nanostructured materials is growing over the last years. The large surface and characteristic conducting properties allow them to achieve better response times, higher sensitivity and improved specificity [23-25]. 
Depending on the electrode material, DNA can be immobilized on the electrode surface using different techniques: physical adsorption, electrochemical adsorption, covalent binding, the use of avidid/biotin complex, or the electropolymerized monomers like pyrrole, with the role of trapping the DNA molecules and binding them to the electrode.

\subsection{Detection principles}

Regardless to the DNA immobilization technique, the fundamental principle of the detection is based on the fact that the electrode detects the change at the DNA molecule. The resulting modification may be due to the change in DNA concentration, orientation (conformation) or structure, caused by damage or denaturation.

On the other hand, modification of the signal can also be caused by the non-covalent interactions of DNA with different ligands. One of the main principles of DNA chemistry is molecular recognition, the process when molecules (small or large) selectively recognize each other. This is manifested through a couple of interaction modes: electrostatic, hydrogen bonds, and van der Waals (dipole - dipole) interaction, which lead to hybridization, association or complex formation. The stability of the formed complex depends on the strength of the mentioned interactions. The most widely used substances that reversible bind to DNA are electroactive intercalators, and by measuring the change in redox signals derived from an electroactive intercalator, the interaction can be followed.

The third type of interaction that can be registered by electrochemical biosensor, are the irreversible interactions among electroactive substances covalently bound to dsDNA (double-stranded, native DNA), used mostly for increasing the selectivity of analytical determination of DNA.

Based on the above mentioned type of interactions, four different detection principles are utilized $[16,17]$.

\subsubsection{Label-free technique}

Label-free technique is based on electrochemical and surface activity of DNA [26, 27]. When nucleic acids interact with electrodes, they are usually strongly adsorbed. The adsorbed nucleic acid undergoes charge-transfer reactions, producing signals that can provide information about their concentration, changes in structure and orientation. Guanine and adenine undergo oxidation processes at glassy carbon electrodes. Oxidation of guanine occurs in two consecutive steps. The first step is irreversible two-electron/twoproton oxidation to 8-oxoguanine, yielding peak at $+0.8 \mathrm{~V}$ vs. $\mathrm{Ag} / \mathrm{AgCl}$ [8], which is followed by one-electron reversible oxidation of the guanine dimers, at $+0.95 \mathrm{~V}$ [28]. The 8-oxoguanine formed at the electrode surface is further oxidized in reversible twoelectron/two-proton process [28]. Adenine oxidation is also irreversible, and occurs in three steps [9]. In cyclic voltammogram of adenine, three peaks are observable: the first one, at $+1.05 \mathrm{~V}$ vs. $\mathrm{Ag} / \mathrm{AgCl}$, corresponds to adenine oxidation, the second at $+1.12 \mathrm{~V}$, to the oxidation of adenine dimmers, and the third one, which is detected after several scans, corresponds to oxidation of adenine electroactive products formed at the electrode surface [28]. DNA oxidation can be followed at other carbon electrodes, such as pyrolytic graphite, carbon paste, modified carbon electrodes, as well as with the tin-oxide electrode. 
At neutral and weakly acidic $\mathrm{pH}$, adenine, cytosine and guanine residues in DNA produce reduction signals at mercury-based electrodes close to $-1.4 \mathrm{~V}$ vs. $\mathrm{Ag} / \mathrm{AgCl}$, and in cyclic modes guanine yields an anodic signal, at about $-0.3 \mathrm{~V}$ vs. $\mathrm{Ag} / \mathrm{AgCl}$, due to the oxidation of its reduction product back to guanine [5]. The $\mathrm{pH}$ of the solution has an important role in the detection process, since protonation of bases is involved in the electrode process. Nucleic acids strongly adsorb on electrodes, especially on mercury and carbon. Ideally smooth and highly reproducible surface of liquid mercury is very well suited for ac (alternating current) impedance measurements, which can provide information about DNA adsorption/desorption properties. This adsorption/ desorption behavior of DNA depends on the structure of the DNA molecules, and its orientation on the electrode surface. Reduction signals of adenine and cytosine are strongly influenced by DNA structure. For example, in differential pulse polarography, the reduction peak of native dsDNA is almost two orders of magnitude smaller then the peak of denatured DNA [29] (Figure 2).

(a)

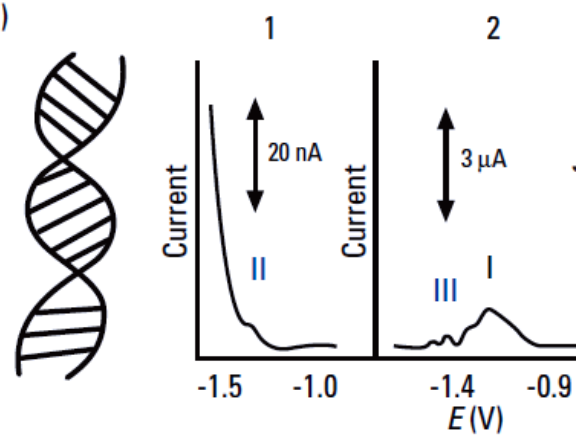

(b)

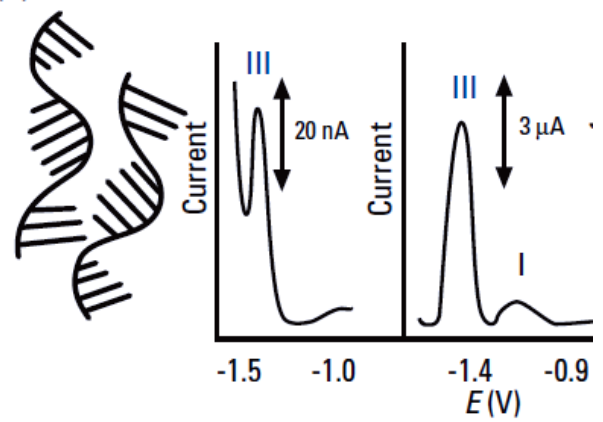

Fig. 2 Redox signals with (a) dsDNA; and (b) ssDNA (single-strand DNA) at mercury electrode. 1- Differential pulse polarography; 2- Adsorptive stripping square wave voltammetry. Faradaic peaks: II - dsDNA, III - ssDNA. Non-Faradaic capacity peak I produced by both dsDNA and ssDNA [29]. 
Also, the non-Faradaic capacity signals are highly sensitive to changes in DNA structure, and can provide information about the bases interactions with the electrode [29]. Since the electrochemical signals are strongly influenced by the DNA structure, mercury electrodes are more suitable for studies of DNA structural transitions and local conformational changes. Experiments with mercury electrodes have identified singlestrand (ss) interruptions in linear and circular DNA molecules, differences in the superhelix density of supercoiled DNAs, and superhelix density dependent structural transitions in DNA [30, 31]. According to all this, electrochemical analysis of DNA can, in principle, be performed without introducing any labels and additional reagents into DNA. Electrochemical reduction and oxidation of nucleobases are irreversible and do not allow reusability of these kind of biosensors.

\subsubsection{Non-covalently bound DNA redox indicators}

The use of DNA redox indicators is an alternative technique used to detect the presence of immobilized DNA as well as its interaction events such as hybridization, damage, and association with another substance. As already mentioned the reduction and oxidation of nucleic acids is chemically irreversible and occurs at highly negative or highly positive potentials. To increase the sensitivity of the measurements, non-covalently binding electroactive markers have been introduced into DNA. These markers undergo reversible electrode reaction at less extreme potentials.

For this purpose soluble redox mediators such as $\mathrm{Rh}$ or $\mathrm{Ru}$ complexes are used to shuttle electrons from guanine residues in distant parts of DNA to the electrode [32]. The redox indicators usually show their electrochemical response at potentials different enough from the nucleobases, and it is often reversible. Some of the indicators interact with DNA through electrostatic forces [33], while others are present "free" in the solution phase. Cationic indicators like metal complex cations such as $\left[\mathrm{Co}(\mathrm{phen})_{3}\right]^{3+}$ and $\left[\mathrm{Co}(\mathrm{bpy})_{3}\right]^{3+}[34$, 35] can be attracted to DNA by negative charge of the backbone, while anionic indicators like $\left[\mathrm{Fe}(\mathrm{CN})_{6}\right]^{3-14-}$ can be repulsed. As a result of this, indicator voltammetric current response is lower and anodic to cathodic peak potential separation is higher than that observed at bare electrodes without DNA $[33,36]$. The electrostatic indicators can also detect differences in negative charge density between ssDNA and dsDNA.

Special kind of redox indicators are intercalators. Intercalators contain planar heterocyclic groups which stack between adjacent DNA base pairs, forming a complex which is stabilized by $\pi-\pi$ stacking interactions between the intercalator and DNA. The most commonly used intercalators are drugs, especially anticancer agents. Intercalators can be mono- or bifunctional, depending on the number of aromatic moieties. There are simple mono-intercalators like acridine, and more complex like daunomycin and adriamycin, as well as bifunctional intercalators as echinomycin and triostin A (Table 1).

Some DNA redox indicators intercalate into the dsDNA structure or bind to dsDNA grooves. The most famous minor groove binding drugs are netropsin, berenil, distamycin and mitramycin. They usually have crescent shape, which complements the shape of the groove [37, 38] and facilitates binding by promoting van der Waals interactions. Considerably small number of substances is reported to bind to major groove: the first reported agent was methyl green [39], and later on some antitumor [40], aminoglycoside antibiotics tobramycin, and other agents as pluramycins, aflatoxins, and azinomycins [41, 42]. 
Table 1 Drugs interacting with DNA, non-covalently and covalently

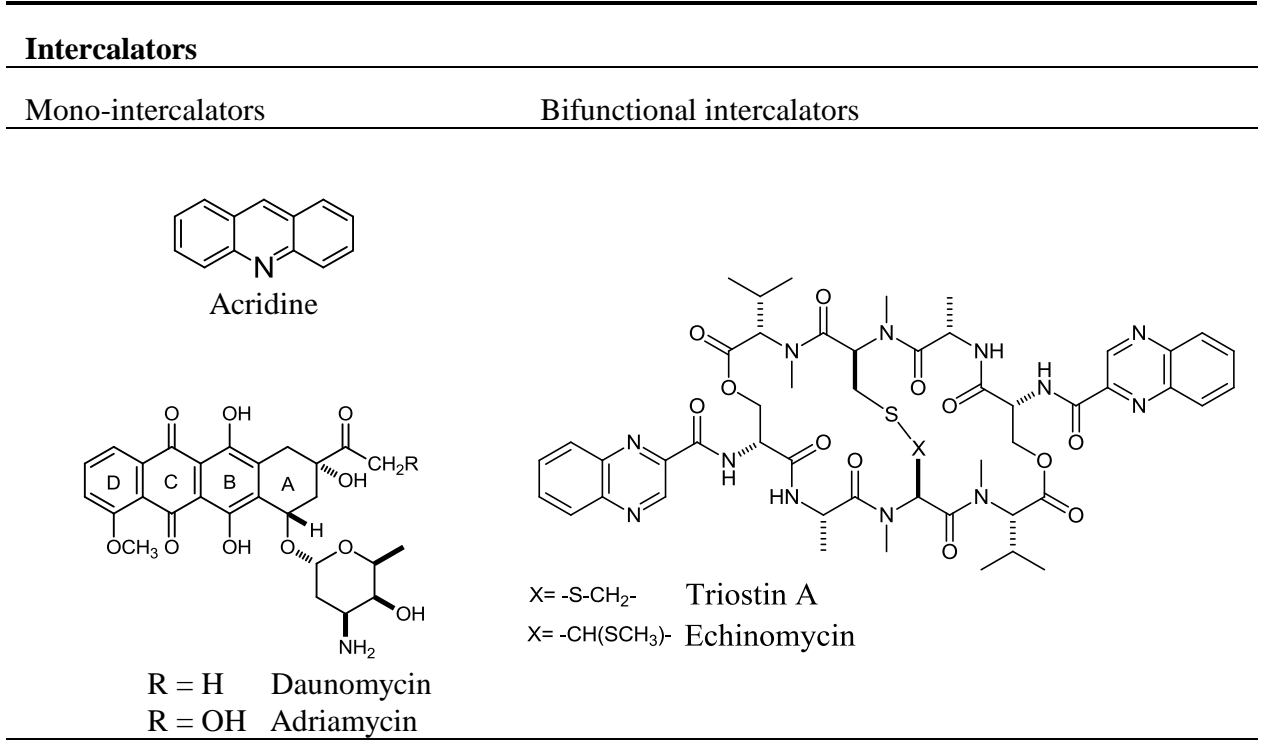<smiles>N[PH](N)(Cl)Cl</smiles>

Cisplatin<smiles>CC1=C(N)C(=O)C2=C(C1=O)N1CC3NC3C21OC(N)=O</smiles>

Mitomycin C<smiles>Cc1ccc2c(c1O)NC(O)C1CC(/C=C/C(N)=O)=CN1C2=O</smiles>

Anthramycin

Due to the accumulation within the immobilized dsDNA layer, the bound redox indicator exhibits a change in voltammetric response. As already mentioned, the most commonly used redox indicators are drugs, especially anticancer agents. For example, daunomycin can be oxidized at low potentials and high current density on a basal plane pyrolytic graphite electrode with an adsorbed DNA probe [43]. This kind of modified electrode detects electrochemical signal derived from an intercalator non-specifically bind to DNA. Voltammetric characteristics such as anodic and cathodic voltammetric peak potential and current obtained at modified graphite electrode are presented in Table 2 [43]. 
Table 2 Anodic and cathodic voltammetric peak potential and current of some intercalators in phosphate buffer, $\mathrm{pH}$ 7.0. (Working electrode pyrolytic graphite, reference electrode $\mathrm{Ag} / \mathrm{AgCl}, \mathrm{v}=25 \mathrm{mVs}^{-1}$ [43].)

\begin{tabular}{lllll}
\hline Intercalator & $\mathrm{E}_{\mathrm{pa}}(\mathrm{mV})$ & $\mathrm{i}_{\mathrm{pa}}(\mu \mathrm{A})$ & $\mathrm{E}_{\mathrm{pc}}(\mathrm{mV})$ & $\mathrm{i}_{\mathrm{pc}}(\mu \mathrm{A})$ \\
\hline $\begin{array}{l}\text { Anthracycline antibiotics } \\
\text { Daunomycin }\end{array}$ & 446 & 2.06 & 394 & 0.34 \\
$\quad \begin{array}{l}\text { Doxorubicin } \\
\text { Pirarubicin }\end{array}$ & 440 & 3.81 & 391 & 0.41 \\
Tetracycline antibiotics & 446 & 1.47 & 389 & 0.26 \\
$\quad$ & & & \\
Tetracycline & 674 & 1.88 & - & - \\
Doxycycline & 663 & 2.79 & - & - \\
Minocycline & 385 & 3.58 & 155 & 0.42 \\
Others & & & & \\
7-Aminoactinomycin D & 651 & 1.34 & 376 & 0.51 \\
Propidium iodide & 631 & 4.84 & 494 & 1.03 \\
Quinacrine mustard & 688 & 2.54 & -73 & 0.32 \\
Rifampicin & 718 & 3.49 & 44 & 0.57 \\
\hline
\end{tabular}

Glassy carbon electrode was used for electrochemical study of in situ anticancer drug adriamycin oxidative damage to DNA [44]. In the study of Tiware et al. [45], DNA modified glassy carbon fiber electrodes were used to study the interaction between the adriamycin and DNA. They reported a formation of an adriamycin radical which is able to oxidize the guanine in the dsDNA, thereby causing the decrease in the guanine oxidation peak. Voltammetric measurements on glassy carbon electrode showed that antileukemia drug glivec binds to dsDNA and leads to modifications in the dsDNA structure, recognized through changes of the anodic oxidation peaks of guanine and adenine bases [46]. Using the same electrode, the decrease of the dsDNA oxidation peaks are detected upon the interaction of microcystin-LR and nodularin with DNA due to the aggregation of DNA strands which may cause the mutations in the dsDNA during the replication process [47]. Similar research involving another anticancer drugs, epirubicin [48] and mitoxantrone [49], reported a decrease in peak current obtained at modified carbon paste electrode upon the interaction of these drugs with DNA. Recently, an anodically activated pencil graphite electrode (PGE) was employed for investigating the mechanism of the interaction between the anticancer drug leuprolide and fish sperm dsDNA, immobilized into the electrode surface [50].

Mercury based electrodes are also used to investigate intercalation reactions mostly based on reduction processes. It is known that some intercalators could distinguish between dsDNA and ssDNA. Data obtained by voltammetric experiments using both the ssDNA and dsDNA modified electrode showed the type of binding of the intercalators. Bard and co-authors $[34,51,52]$ reported that positive shifts of the peak potential were observed in the binding form via hydrophobic interactions (intercalation), while electrostatic interactions led to negative shift. Electrochemistry of anti tumor drugs echinomycin [53], and acridine [54], as well as nicotinic partial agonist varenicline [55], and their interaction with DNA were studied on hanging mercury drop electrode. In all cases a formation of drug-DNA complex was reported and the binding constant values determined. 
Several other electrodes have been exploited in these studies. Among them modified gold surfaces are very often used. The self-assembled monolayers (SAMs) of an azidohexane thiol derivative were prepared on the Au electrode, and then used for the immobilization of dsDNA and investigation of interactions of taxol, a very important anticancer drug, and DNA [56]. This was done by monitoring the guanine oxidation peak current. Sun at al. [57] used daunomycin intercalated into a dsDNA as a biosensor to investigate the relation between peak current and the concentration of the DNA at modified gold electrode.

Intercalators are also used as a part of DNA hybridization detectors. In an electrochemical DNA hybridization detector a short DNA probe is usually immobilized on electrode to create a DNA recognition element. The probe-modified electrode is then immersed into a solution of target DNA. When the target DNA contains a sequence that exactly matches that of the probe DNA, a hybrid duplex is formed at the electrode surface. In the absence of complementarities between the probe and target, no duplex is formed. A DNA sensor recognizes the hybrids using an intercalator as an electrochemical probe. It is confirmed that intercalator is bound to hybrid more specifically than to DNA probe in order to detect a specific gene with high sensitivity [51].

Due to the recent progress in the analysis of nucleic acids, peptides and proteins, the electrochemical methods appear ready for application to sequence-specific and nonspecific interactions of proteins with DNA. Peptides, polyaminoacids and proteins produce a structure-sensitive chronopotentiometric peak at mercury electrodes, which is due to the catalytic hydrogen evolution reaction. This characteristic reaction was used in the investigation of basic protein like histones, binding to DNA [58], as well as in the research on the aggregation of $\alpha$-synnuclein in Parkinson's disease [59], and mutation of tumor suppressor proteins p53 [60].

\subsubsection{Covalently bound electrochemically active DNA labels}

Electrochemically active DNA labels (tracers) are compounds covalently bound to DNA, which are used for the DNA detection with improved analytical selectivity and specificity [22, 26, 61]. Most common used labels are modified ferrocene [62], nitrophenyl and aminophenyl groups, as well as osmium tetroxide complexes with nitrogen ligands [63-65]. Osmium tetroxide complexes were the first electroactive markers that were covalently bound to DNA. Some of these complexes bind preferentially to thymine residues in ssDNA, while others bind both to dsDNA and ssDNA. DNA adducts with these complexes produce reversible signals between $-0.2 \mathrm{~V}$ and $-0.7 \mathrm{~V}$ vs. $\mathrm{Ag} / \mathrm{AgCl} / 3 \mathrm{M}$ $\mathrm{KCl}$ at both carbon and mercury electrodes, and a high catalytic signal at $-1.2 \mathrm{~V}$ vs. $\mathrm{Ag} / \mathrm{AgCl} / 3 \mathrm{M} \mathrm{KCl}$ at mercury electrodes. Using the catalytic signal, the sensitivity is two orders of magnitude higher than the signal of unmodified ssDNA (Figure 3), [29].

Some drugs interact covalently with DNA molecule [66]. Covalent binding in DNA is irreversible and undoubtedly leads to complete inhibition of DNA functions and subsequent cell death. The most famous covalent binder is Cisplatin (Table 1), which is used as an anticancer drug. When used for clinical practice, cisplatin is administered intravenously. In the extracellular environment, where the chloride concentration is high, it does not undergo appreciable hydrolysis. 
a)

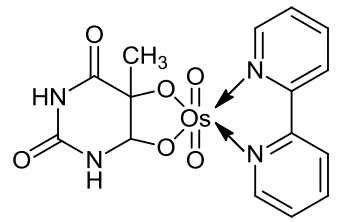

b)

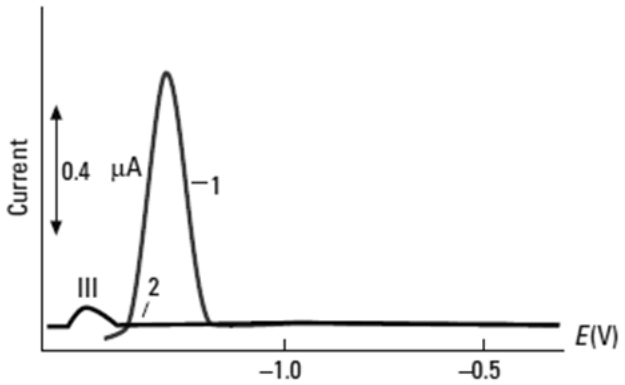

Fig. 3 Differential pulse polarography of the complex obtained with $\mathrm{OsO}_{4}$ in the presence of 2,2'-bipy and thymine. Curve 1 - ssDNA modified with osmium complex;

Curve 2 - unmodified ssDNA [29].

When cisplatin passes the cell membrane the reduced intracellular chloride concentration allows the chloro ligands to be replaced by water molecules to form cis$\left[\mathrm{Pt}\left(\mathrm{H}_{2} \mathrm{O}\right)\left(\mathrm{NH}_{3}\right)_{2} \mathrm{Cl}\right]^{+}$and cis- $\left[\mathrm{Pt}\left(\mathrm{H}_{2} \mathrm{O}\right)_{2}\left(\mathrm{NH}_{3}\right)_{2}\right]^{2+}$. It is generally accepted that these two cations bind covalently to the electron-rich sites on DNA such as $N$-donor ligands [67]. The preferred target in DNA is guanine $(\mathrm{G})$ since it has the highest electron density of all four nucleobases. It is believed that this reaction is responsible for the anticancer effect of cisplatin which is able to induce apoptosis/necrosis of the cancer cell [68].

The use of electrochemical techniques for studying platinum-DNA interactions were reported by Brabec [69] and by Erdem et al. [70], who studied the binding of cisplatin and a cisplatin-like chemotherapeutic agent to DNA which was coated on a wax-impregnated graphite electrode and a pencil graphite electrode, respectively, by using differential pulse voltammetry. Besides, Oliveira Brett et al. reported the electrochemical determination of carboplatin in serum using a DNA-modified glassy carbon electrode [71].

Mascini et al. have developed biosensors involving binding of cisplatin, carboplatin, platinum bipy and oxaliplatin [72-74] to double-stranded DNA immobilized on the surface of screen-printed electrodes (SPEs). These biosensors use chronopotentiometry or square wave voltammetry (SWV), to rapidly and quantitatively measure the decrease of the oxidation peak of guanine. By calculating the ratio between the area (or height) of the guanine oxidation peak after interaction with the drug, and the area obtained by DNA alone, the percent of guanine sites in DNA that have not been modified by the interaction can be estimated.

The attempt to use non-platinum metal complexes as anticancer agents was initiated with an idea to find less toxic and more specific drugs. Some ruthenium and titanium complexes showed promising pharmacological properties as antitumor and antimetastatic agents. The interaction of ruthenium(III) complex, NAMI-A, with dsDNA immobilized on screenprinted electrodes was studied as a screening tool for in vitro DNA-drug interaction [75]. Titanium(IV) complex titanocene showed a lower degree of interaction with DNA than cisplatin since the ionic interaction between $\mathrm{Ti}$ cation and external phosphate backbone produces a minor effect on the oxidation of $\mathrm{G}$ with respect to the direct coordination [76].

This approach that has been successfully employed for the study of the interaction between a series of antitumor metallo-drugs and DNA offers information concerning the 
reactivity of the metal complex, the effect of anions acting as leaving ligands, the affinity of the generated electrophilic agent to DNA, and the strength of perturbation caused in the DNA chain by these metallo-drugs.

\subsubsection{Nanostructured and magnetic materials}

In the last decade, the use of nanostructured materials is spreading in the field of nanosensors. This class of materials such as carbon nanotubes, magnetic nanoparticles or metal nanoparticles possesses very attractive features. Carbon nanotubes have recently attracted considerable attention due to their unique structural, electronic, mechanical and chemical properties [77]. The large specific surface and characteristic conducting properties allow them to achieve better response times, higher sensitivity and improved specificity [23]. Aligned carbon nanotubes were used to detect a DNA sequence characteristic for genetically modified organisms with sensitivity in the nanomolar range [24].

Magnetic separation represents an alternative method for DNA binding to solid surface, which offers faster and less time consuming procedure. This method uses the magnetism for efficient separation of micrometer-sized paramagnetic or ferromagnetic particles from biological or chemical media. These particles, so called magnetic beads, become magnetic under strong magnetic field, but retain no magnetism in the absence of magnetic field. Magnetic beads can be prepared in various ways. Usually particles susceptible to magnetism, such as iron oxide, are coated with biological or synthetic polymers [78]. A combination of magnetic beads for immuno-magnetic separation and a later detection step using magnetic graphite-epoxy composite electrode has been recently employed for the detection of Salmonella in milk with the very low limit of detection [25].

Nanoparticles or nanocrystals of gold, silver, indium, zinc, cadmium or lead chalogenides have been used as well $[79,80]$.

A nanoparticle-based electrical detection of DNA hybridization, based on electrochemical stripping detection of the colloidal gold tag is reported by J. Wang et al. [81]. In this work the hybridization of a target oligonucleotide to magnetic bead-linked oligonucleotide probes is followed using an advanced magnetic processing technique to isolate the DNA duplex and to provide low-volume mixing. Another electrochemical DNA detection method has been developed for the sensitive quantification of an amplified human cytomegalovirus DNA sequence (HCMV DNA). The assay relies on the hybridization of the single-stranded target HCMV DNA with an oligonucleotide-modified Au nanoparticle probe, followed by the release of the gold metal atoms, anchored on the hybrids by oxidative metal dissolution, and the indirect determination of the solubilized $\mathrm{Au}(\mathrm{III})$ ions by anodic stripping voltammetry at a sandwich-type screen-printed microband electrode (SPMBE) [82].

An electrochemical DNA hybridization detection assay, using silver nanoparticles as the oligonucleotide labeling tag, is reported [83]. The assay relies on the hybridization of the target DNA with the silver nanoparticle-oligonucleotide DNA probe, followed by the release of the silver metal atoms, its oxidative dissolution and indirect determination of the solubilized $\operatorname{Ag}(\mathrm{I})$ ions by anodic stripping voltammetry (ASV) at a carbon fiber ultramicroelectrode. Finally, Wang and coauthors proposed silver-enhanced colloidal gold stripping detection strategy for the detection of DNA hybridization which represents an alternative to indirect optical affinity assays of nucleic acids and other biomolecules [84]. 


\section{CONCLUSIONS}

Having in mind that DNA is one of the most important biomacromolecules, the possibility of construction of DNA-based sensor deserves great attention. Such biosensor is simple, fast, cheap, miniaturized and easy-controlled analytical device for investigation DNA chemical and physical interactions with other small molecules in vitro. According to all these properties, it is understandable that DNA biosensors are finding their application as drug investigation devices, in chemical toxicity tests, and in food and water analysis. Besides, these biosensors are used for fundamental evaluation of effects of antioxidants, and investigation of interactions of nucleic acids with other biomacromolecules such as proteins, that contributes to development of molecular diagnostics.

\section{REFERENCES}

1. R. Boyer, Concepts in biochemistry, $3^{\text {rd }}$ Edition, John Wiley \& Sons, Hoboken, New Jersey, 2006.

2. D.J. Voet, J.G. Voet and C.W. Pratt, Principles of biochemistry, John Wiley \& Sons, Hoboken, New Jersey, 2008.

3. G.L. Zubay, W.W. Parson and D.E. Vance, The principles of biochemistry, McGraw-Hill College, Boston, 1995

4. E. Palecek, Oscillographic polarography of highly polymerized deoxyribonucleic acid, Nature, 188, 656-657 (1960).

5. E. Palecek, Oscillographic polarography of guanine residues in deoxyribonucleic acid, Collection of Czechoslovak Chemical Communication, 31, 2360-2373 (1966).

6. B. Janik and E. Palecek, Polarographic behavior of cytosine and some of its derivatives, Archives of Biochemistry and Biophysics, 105 (2), 225-236 (1966).

7. V. Bravec, Nucleic acid analysis by voltammetry at carbon electrodes, Bioelectrochemistry and Bioenergetics, 8, 437-449 (1981).

8. A.M. Oliveira-Brett, J.A.P. Piedade and S.H.P. Serrano, Electrochemical oxidation of 8oxoguanine, Electroanalysis, 12, 969-973 (2000).

9. G. Druyhurst and P.J. Elving, Electrochemical oxidation of adenine: reaction products and mechanisms, Journal of the Electrochemical Society, 115, 1014-1020 (1968).

10. D.R. Thévenot, K. Toth, R.A. Durst, and G. S. Wilson, Electrochemical biosensors: recommended definitions and classification, Biosensors and Bioelectronics, 16 (1-2), 121-131 (2001).

11. J. Negandhi, A. Ray and P. Vadgama, Biosensors in Biomedical Sensors D.P. Jones, Ed., Momentum Press, New York, 2010.

12. Jan Labuda, Terminology Related to Electrochemical DNA-Based Biosensors, in Electrochemical DNA biosensors, M. Ozsoz, Ed., Pan Stanford Publishing Singapore, 2012.

13. F.R.R. Teles and L.P. Fonseca, Trends in DNA biosensors, Talanta, 77 (2), 606-623 (2008).

14. K. Kerman, M. Kobayashi and E. Tamiya, Recent trends in electrochemical DNA biosensor technology, Measurement Science and Technology, 15 (2), R1- R11 (2004).

15. X. Tian, Y. Song, H. Dong and B. Ye, Interaction of anticancer herbal drug berberine with DNA immobilized on the glassy carbon electrode, Bioelectrochemistry, 73 (1), 18-22 (2008).

16. D. Šimkova and J. Labuda, Electrochemical DNA biosensors and flow-through analysis, Current Analytical Chemistry, 7, 2-7 (2011).

17. J. Labuda, M. Fojta, F. Jelen and E. Palecek, in Encyclopedia of sensors, C.A. Grimes, E.C. Dickey and M.V. Pishko, Eds., American Scientific Publishers, Stevenson Ranch, USA, 2006.

18. J. Wang, Electrochemical nucleic acid biosensors, in Electrochemistry of nucleic acids and proteins. Towards electrochemical sensors for genomics and proteomics, E. Palecek, F. Scheller and J. Wang, Eds., Elsevier, Amstredam Science B.V., 2005.

19. R. Ovádeková and J. Labuda, Electrochemical DNA biosensors for the investigation of dsDNA host-guest interactions and damage, Current Topics in Electrochemistry, 11, 21-56 (2006). 
20. A.M.O. Brett, V.C. Diculescu, A.M. Chiorcea-Paquim and S.H.P. Serrano, in Electrochemical sensors analysis, S. Alegret and A. Merkoci, Eds., Elsevier Science B.V., Amsterdam, 2007.

21. R. Ovádeková and J. Labuda, in Utilizing of bio-electrochemical and mathematical methods in biological research, V. Adam and R. Kizek, Eds., Research Signpost, Kerala, India, 2007.

22. J. Labuda, A.M.O. Brett, G. Evtugyn, M. Fojta, M. Mascini, M. Ozsoz, I. Palchetti, E. Paleček and J. Wang, Electrochemical nucleic acid-based biosensors: concepts, terms and methodology, IUPAC Technical Report, Pure and Applied Chemistry, 82, 1161-1187 (2010).

23. K.M. Abu-Salah, S.A. Alrokyan, M.N. Khan and A.A. Ansari, Nanomaterials as analytical tools for genosensors, Sensors, 10 (1), 963-993 (2010).

24. F. Berti, L. Lozzi, I. Palchetti, S. Santucci and G. Marrazza, Aligned carbon nanotube thin films for DNA electrochemical sensing, Electrochimica Acta, 54, 5035-5041 (2009).

25. S. Liébana, A. Lermo, S. Campoy, J. Barbé, S. Alegret and M.I. Pividori, Magneto immunoseparation of pathogenic bacteria and electrochemical magneto genosensing of the double-tagged amplicon, Analytical Chemistry, 81 (14), 5812-5820 (2009).

26. E. Palecek and F. Jelen, Electrochemistry of nucleic acids, in Electrochemistry of nucleic acids and proteins. Towards electrochemical sensors for genomics and proteomics, E. Palecek, F. Scheller and J. Wang, Eds., Elsevier Science B.V., Amsterdam, 2005.

27. E. Paleček and V. Brabec, The relation between the polarographic behaviour of DNA and its conformation in solution, Biochimica and Biophysica Acta, 262, 125-134 (1972).

28. A.M.O. Brett, V.C. Diculescu, J.A.P. Piedade, Electrochemical oxidation mechanism of guanine and adenine using a glassy carbon microelectrode, Bioelectrochemistry, 55, 61-62 (2002).

29. E. Palecek and M. Fojta, Detecting DNA hybridization and damage, Analytical Chemistry, 73 (3), 74A-83A (2001).

30. E. Palecek, in Topics in bioelectrochemistry and bioenergetics, G. Milazzo, Ed., John Wiley, Chichester, 1983

31. M. Fojta, R.P. Bowater, V. Stankova, L. Havran, D.M.J. Lilley and E. Palecek, Two superhelix density-dependent DNA transitions detected by changes in DNA. Adsorption/desorption behavior, Biochemistry, 37, 4853-4862 (1998).

32. N.D. Popovich and H.H. Thorp, New strategies for electrochemical nucleic acid detection, Interface, 11, 30-34 (2002).

33. J. Labuda, M. Buckova, M. Vanickova, J. Mattusch and R. Wennrich, Voltammetric detection of the DNA interaction with copper complex compounds and damage to DNA, Electroanalysis, 11, 101-107 (1999).

34. M.T. Carter and A.J. Bard, Voltammetric studies of the interaction of tris(1,10-phenanthroline)cobalt(III) with DNA, Journal of the American Chemical Society, 109, 7528-7530 (1987).

35. X. H. Xu and A.J. Bard, Immobilization and hybridization of DNA on an Aluminum(III) alkanebisphosphonate thin film with electrogenerated chemiluminescent detection, Journal of the American Chemical Society, 117, 2627-2631 (1995).

36. J. Labuda, R. Ovadekova and J. Galandova, DNA-based biosensor for the detection of strong damage to DNA by the quinozaline derivative as a potential anticancer drug, Microchimica Acta, 164, 371-377 (2009).

37. Z. Moravek, S. Neidle and B. Schneider, Protein and drug interactions in the minor groove of DNA, Nucleic Acids Research, 30, 1182-1191 (2002).

38. S. Neidle, DNA minor groove recognition by small molecules, Natural Product Reports, 18, 291309 (2001).

39. S.K. Kim and B. Norden, Methyl green A DNA major-groove binding drug, Federation of European Biochemical Society Letters, 315 (1), 61-64 (1993).

40. S. Neidle, Principles of nucleic acid structure, Elsevier, Amsterdam, 2008.

41. N.N. Singh and A.M. Lambowitz, Interaction of a group II intron ribonucleoprotein endonuclease with its DNA target site investigated by DNA footprinting and modification interference, Journal of Molecular Biology, 309 (2), 361-386 (2001).

42. P.L. Hamilton and D.P. Arya, Natural product DNA major groove binders, Natural Product Reports, 29, 134-143 (2012). 
43. K. Hashimoto, K. Ito and Y. Ishimori, Novel DNA sensor for electrochemical gene detection, Analytical Chimica Acta, 286, 219-224 (1994).

44. A.M.O. Brett, M. Vivan , I.R. Fernandes and J.A.P. Piedade, Electrochemical detection of in situ adriamycin oxidative damage to DNA, Talanta, 56, 959-970 (2002).

45. S. Tiwary and K.S. Pitre, Voltammertric DNA biosensor for the study of mechanism of action of anticancer drug-adriamycin, Indian Journal of Chemical Technology, 15, 593-597 (2008).

46. V.C. Diculescu, M. Vivan and A.M.O. Brett, Voltammetric behavior of antileukemia drug glivec. Part III: In situ DNA oxidative damage by the glivec electrochemical metabolite, Electroanalysis, 18 (19-20), 1963-1970 (2006).

47. P.V.F. Santos, I.C. Lopes, V.C. Diculescu and A.M.O. Brett, DNA - Cyanobacterial Hepatotoxins Microcystin-LR and Nodularin Interaction: Electrochemical Evaluation, Electroanalysis, 24 (3), 547-553 (2012)

48. A. Erdem and M. Ozsoz, Interaction of the anticancer drug epirubicin with DNA, Analytica Chimica Acta, 437, 107-114 (2001).

49. A. Erdem and M. Ozsoz, Interaction of the anticancer drug mitoxantrone and DNA, Turkish Journal of Chemistry, 25, 469-475 (2001).

50. B. Dogan-Topal and S.A. Ozkan, A novel sensitive electrochemical DNA biosensor for assaying of anticancer drug leuprolide and its adsorptive stripping voltammetric determination, Talanta, 83, 780-788 (2011).

51. A.J. Bard, M.T. Cater and M. Rodoriguez, Voltammetric studies of the interaction of metal chelates with DNA. 2. Tris-chelated complexes of cobalt(III) and iron(II) with 1,10-phenanthroline and 2,2'-bipyridine, Journal of the American Chemical Society, 111, 8901-8911 (1989).

52. A.J. Bard and M. Rodoriguez, Electrochemical studies of the interactions of metal chelates with DNA, Analytical Chemistry, 62, 2658-2662 (1990).

53. F. Jelen, A. Arzum and E. Palecek, Cyclic voltammetry of echinomycin and its interaction with doublestranded and single-stranded DNA adsorbed at the electrode, Bioelectrochemistry, 55, 165-167.

54. F.A. Rashwan, M.S. Ibrahim, M.M. Kamal, A.M.Awada and M. Khairy, Electrochemistry of acridine antitumor drug and its interaction with DNA, Global Journal of Physical Chemistry, 3, 7- (2012).

55. V. Radulović, M.M. Aleksić and V. Kapetanović, An electrochemical study of the adsorptive behaviour of varenicline and its interaction with DNA, Journal of the Serbian Chemical Society, 77 (10), 1409-1422 (2012).

56. A. Mehdinia, S.H. Kazemi, S.Z. Bathaie, A. Alizadeh, M. Shamsipur and M.F. Mousavi, Electrochemical studies of DNA immobilization onto the azide-terminated monolayers and its interaction with taxol, Analytical Biochemistry, 375, 331-338 (2008).

57. X. Sun, P. He, S. Liu, J. Ye and Y. Fang, Immobilization of single-stranded deoxyribonucleic acid on gold electrode with self-assembled aminoethanethiol monolayer for DNA electrochemical sensor applications, Talanta, 47 (2), 487-495 (1998).

58. M. Živanović, M.M. Aleksić, V. Ostatná, T. Doneux and E. Paleček, Polylysine-catalyzed hydrogen evolution at mercury electrodes, Electroanalysis, 22 (17-18), 2064-2070 (2010).

59. E. Palecek, V. Ostatna, M. Masarik, C.W. Bertoncini and T.M.Jovin, Changes in interfacial properties of $\alpha$-synuclein preceding its aggregation, Analyst, 133, 76-84 (2008).

60. E. Palecek, V. Ostatna, Electroactivity of nonconjugated proteins and peptides. Towards electroanalysis of all proteins, Electroanalysis, 19 (23), 2383-2403 (2007).

61. E. Paleček and M. Fojta, Magnetic beads as versatile tools for electrochemical DNA and protein biosensing, Talanta, 74, 276-290 (2007).

62. M. Hocek and M. Fojta, Cross-coupling reactions of nucleoside triphosphates followed by polymerase incorporation. Construction and applications of base-functionalized nucleic acids, Organic and Biomolecule Chemistry, 13, 2233-2241 (2008).

63. M. Fojta, P. Kostecka, M. Trefulka, L. Havran and E. Palecek, "Multicolor" electrochemical labeling of DNA hybridization probes with osmium tetroxide complexes, Analytical Chemistry, 79, 1022-1029 (2007).

64. G.U. Flechsig and T. Reske, Electrochemical detection of DNA hybridization by means of osmium tetroxide complexes and protective oligonucleotides, Analytical Chemistry, 79, 2125-2130 (2007). 
65. M. Trefulka, V. Ostatna, L. Havran, M. Fojta and E. Paleček, Covalent labeling of nucleosides with VIII- and VI-valent osmium complexes, Electroanalysis, 19, 1281-1287 (2007).

66. O. Kennard, DNA-drug interactions. Pure and Applied Chemistry, 65 (6), 1213-1222 (1993).

67. S. J. Berners-Price and T. G. Appleton, The chemistry of cisplatin in aqueous solution, in Platinum-Based Drugs in Cancer Therapy, L. R. Kelland, Ed., pp. 3-35, Humana Press, Totowa, NJ, USA, 2000

68. M. A. Jakupec, M. Galanski, and B. K. Keppler, Tumour inhibiting platinum complexes-state of the art and future perspectives, Reviews of Physiology Biochemistry and Pharmacology, 146, 1-53 (2003).

69. V. Brabec, DNA sensor for the determination of antitumor platinum compounds, Electrochimica Acta, 45, 2929-2932 (2000).

70. A. Erdem, B. Kosmider, R. Osiecka, E. Zyner, J. Ochocki and M. Ozsoz, Electrochemical genosensing of the interaction between the potential chemotherapeutic agent, cis-bis(3aminoflavone)dichloroplatinum(II) and DNA in comparison with cis-DDP, Journal of the Pharmaceutical and Biomedical Analysis, 38, 645-652 (2005).

71. A.M. Oliveira Brett, S.H.P. Serrano, T.A. Macedo, D. Raimundo, M.H. Marques and M.A. LaScalea, Electrochemical determination of carboplatin in serum using a DNA-modified glassy carbon electrode, Electroanalysis, 8, $992-995$ (1996).

72. M. Mascini, G. Bangi, M. L. Di Pietro, M. Ravera, S. Baracco, and D. Osella, Electrochemical biosensor evaluation of the interaction between DNA and metallo-drugs, Biometals, 19(4), 409-418 (2006).

73. M. Ravera, G. Bagni, M. Mascini, J.C. Dabrowiak, D. Osella, The activation of platinum(II) antiproliferative drugs in carbonate medium evaluated by means of a DNA-biosensor, Journal of Inorganic Biochemistry, 101, 1023-1027 (2007).

74. M. Ravera, G. Bagni, M. Mascini, and D. Osella, DNA-Metallodrugs Interactions Signaled by Electrochemical Biosensors: An Overview, Bioinorganic Chemistry and Applications, Article Number 91078, DOI: 10.1155/2007/91078 (2007).

75. G. Bagni, M. Ravera, D. Osella and M. Mascini, Electrochemical biosensors as a screening tool of in vitro DNA-drug interaction, Current Pharmaceutical Analysis, 1, 217-224 (2005).

76. G. Bagni, D. Osella, E. Sturchio and M. Mascini, Deoxyribonucleic acid (DNA) biosensors for environmental risk assessment and drug studies, Analytica Chimica Acta, 573-574, 81-89 (2006).

77. R. Polsky, J.C. Harper and S.M. Brozik, Nanomaterial-based electrochemical DNA detection, in Electrochemical DNA biosensors, M. Ozsoz, Ed., Pan Stanford Publishing Singapore, 2012.

78. S. Berensmeier, A procedure for the isolation of deoxyribonucleic acid from micro-organisms, Journal of Molecular Biology, 3, 208-218 (1961).

79. J. Wang, Nanoparticle-based electrochemical DNA detection, in Electrochemistry of nucleic acids and proteins. Towards electrochemical sensors for genomics and proteomics, E. Palecek, F. Scheller and J. Wang, Eds., Elsevier Science B.V., Amsterdam, 2005.

80. M. Pedrero, P. Yanez-Sadeno and J.M. Pingarron, Gold Nanoparticles-based electrochemical DNA biosensors, in Electrochemical DNA biosensors, M. Ozsoz, Ed., Pan Stanford Publishing Singapore, 2012.

81. J. Wang, D. Xu, A.N. Kawde, R. Polsky, Metal Nanoparticle-Based Electrochemical Stripping Potentiometric Detection of DNA Hybridization, Analytical chemistry, 73, 5576-5581 (2001).

82. L. Authier, C. Grossiord, P. Brossier, and B. Limoges, Gold Nanoparticle-Based Quantitative Electrochemical Detection of Amplified Human Cytomegalovirus DNA Using Disposable Microband Electrodes, Analytical chemistry, 73, 4450-4456 (2001).

83. H. Cai, Y.Hu, N. Zhu, P. He, Y. Fang, An electrochemical DNA hybridization detection assay based on a silver nanoparticle label, Analyst, 127, 803-808 (2002).

84. J. Wang, R. Polsky and X. Danke, Silver-Enhanced Colloidal Gold Electrochemical Stripping Detection of DNA Hybridization, Langmuir, 17, 5739-5741 (2001). 


\section{PRIMENA ELEKTROHEMIJSKIH BIOSENZORA ZA ISPITIVANJE STRUKTURE, OŠTEĆENJA I INTERAKCIJA DNK SA DRUGIM MOLEKULIMA}

Poslednjih godina je postignut veliki napredak u razvoju elektrohemijskih biosenzora za ispitivanja sekvenci, hibridizacije i oštećenja na molekulu DNK. Primenom elektrohemijskih metoda se u današnje vreme mogu detektovati $i$ određivati nanomolarne koncentracije DNK. Pored toga, ove metode su pogodne za ispitivanje kako kovalentnih, tako i nekovalentnih interakcija između DNK i različitih malih molekula, kakvi su lekovi i drugi potencijalno mutageni agensi. Ovo sugeriše da bi elektrohemijski biosenzori mogli biti od značaja i u oblast medicinskih istraživanja. Cilj ovoga preglednog rada je da skrene pažnju na primenljivost različitih elektrohemijskih metoda za proučavanje interakcija između DNK i drugih molekula, kao i u izradu novih osetljivih i selektivnih biosenzora.

Ključne reči: elektrohemijski biosenzor, DNK, interakcije, oštećenja 